\title{
Kernos
}

Revue internationale et pluridisciplinaire de religion grecque antique

$24 \mid 2011$

Varia

\section{The Thracian Cult of Rhesus and the Heros Equitans}

\section{Vayos Liapis}

\section{OpenEdition}

\section{Journals}

\section{Electronic version}

URL: https://journals.openedition.org/kernos/1938

DOI: 10.4000/kernos. 1938

ISSN: 2034-7871

\section{Publisher}

Centre international d'étude de la religion grecque antique

\section{Printed version}

Date of publication: 1 January 2011

Number of pages: 95-104

ISSN: 0776-3824

Electronic reference

Vayos Liapis, "The Thracian Cult of Rhesus and the Heros Equitans", Kernos [Online], 24 | 2011, Online since 01 February 2014, connection on 21 September 2021. URL: http://journals. openedition.org/

kernos/1938; DOI: https://doi.org/10.4000/kernos.1938 
Kernos 24 (2011), p. 95-104.

\title{
The Thracian Cult of Rhesus and the Heros Equitans
}

\begin{abstract}
A survey of the available evidence for the Thracian cult of Rhesus, mainly on the basis of the pseudo-Euripidean Rhesus and of Philostratus' Heroicus, shows that the identification of Rhesus with the so-called Heros Equitans, or "Thracian Horseman" (first proposed almost a century ago by G. Seure) rests on firmer ground than is sometimes assumed. The paper also reviews significant portions of the pictorial and epigraphic evidence for the Heros Equitans. It concludes that the parallels between Rhesus and the Heros Equitans are too striking to be ignored.

Résumé : Un relevé analytique de la documentation disponible sur le culte thrace de Rhésos, se fondant surtout sur le Rhésos du pseudo-Euripide et sur l'Heroikos de Philostrate, montre que l'identification de Rhésos avec le prétendu «Heros Equitans» ou «Cavalier thrace» (d'abord proposée, il y a près d'un siècle, par G. Seure) repose sur des fondements plus assurés qu'on ne le pense parfois. Cet article passe également en revue des parties significatives de la documentation iconographique et épigraphique pour le Heros Equitans. On en conclut que le parallélisme entre ce dernier et Rhésos est trop frappant pour être ignoré.
\end{abstract}

\section{Introduction}

The tragedy of Rhesus, traditionally attributed to Euripides, ${ }^{1}$ provides the oldest extant evidence on the cult of Rhesus in the Balkan peninsula. The rest of our information must be pieced together from late literary sources, which are not always above suspicion, and from the archaeological record. Fragmentary and open to doubt as it is, the evidence does nonetheless suggest that the cult of Rhesus, or of a figure closely related to him (specifically, the so-called Heros Equitans, on which more in section 2 below), was indigenous to ancient Macedonia and Thrace. To the extent that they can be reconstructed, matrices of Rhesus-cult that appear to be epichoric in that area are incompatible with the standard modalities of, at least, Athenian hero-cult - although they do bear comparison with some Greek cults for denizens of subterranean chambers. The

${ }^{*}$ I am grateful to Pierre Bonnechere and to an anonymous reader for Kernos for their criticisms and suggestions. All errors are mine.

${ }^{1}$ On the question of the authenticity of Rhesus see most recently (with further bibliography) V. LIAPIS, "Rhesus Revisited: The Case for a Fourth-Century Macedonian Context," JHS 129 (2009), p. 71-88; for a full-scale commentary on the play see again LIAPIS, A Commentary on the Rhesus Attributed to Euripides, Oxford, Oxford University Press, forthcoming in 2012. 
topic has been dealt with in detail in an earlier article of mine; ${ }^{2}$ here I shall supplement that paper's argument with considerations on the possible affinities between Rhesus and the Heros Equitans.

\section{The Thracian cult of Rhesus: insights from Rhesus and elsewhere}

In her aetiological narrative towards the end of Rhesus (962-973), Rhesus' mother, a Muse, describes her son's posthumous fate, and declares that he will not 'go under the black earth' (962) but will rather continue his existence by assuming a new identity as $\alpha \nu \theta \varrho \omega \pi 0 \delta \alpha i \mu \omega \nu$, 'man-god', namely an entity betwixt and between man and deity (971). ${ }^{3}$ In this new interstitial capacity, the Muse says, Rhesus will inhabit forever a subterranean cavern somewhere in Mt. Pangaeum, and will act as 'prophet of Bacchus' (970-973). All of this has been sometimes dismissed as poetic fancy, most vehemently perhaps by W. Leaf, ${ }^{4}$ who invoked Cicero's statement to the effect that there was no cult of Rhesus anywhere in the ancient world. ${ }^{5}$ However, apart from the fact that this can at best have been valid only for Cicero's own time, ${ }^{6}$ there is no evidence that Cicero founded his statement on serious Alexandrian scholarship, as Leaf thought. ${ }^{7}$ On the contrary, the De natura deorum contains a number of misunderstandings and false assumptions, and Cicero does sometimes seem to have given himself a free hand in the treatment of his sources. ${ }^{8}$

Importantly, Cicero's sweeping statement is contradicted by Philostratus (probably L. Flavius Philostratus), who gives in his Heroicus an account of Rhesus' cult as it obtained apparently in his own era (3rd century A.D.). ${ }^{9}$ According to it,

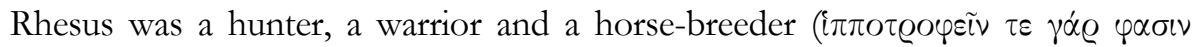

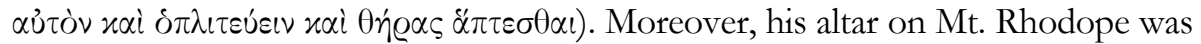
frequented by wild animals that offered themselves willingly to be sacrificed to

\footnotetext{
2 V. LiAPIS, “Zeus, Rhesus, and the Mysteries,” CQ 57 (2007), p. 381-411, esp. 408-411.

3 On Rhesus' intermediate state, betwixt and between mortality and immortality, see also C. Plichon, “Le Rhésos et l'orphisme,” Kernos 14 (2001), p. 11-21, here 19-20.

${ }^{4}$ W. LEAF, "Rhesos of Thrace," JHS 35 (1915), p. 1-11, here 4.

${ }^{5}$ See De natura deorum III, 45.

${ }^{6}$ For this obvious criticism of. e.g. E. RoHDE, Psyche. The Cult of Souls and Belief in Immortality among the Greeks, transl. W. B. Hillis, London, 1925, p. 143 n. 36; P. Perdrizet, Cultes et mythes $d u$ Pangée, Paris/Nancy, 1910, p. 20; I. MaLkin, Religion and Colonization in Ancient Greece, Leiden, 1987, p. 82.

${ }^{7}$ See on this point J. Rempe, De Rheso Thracum heroe, diss., Münster, 1927, p. 33.

8 Cf. A R. Dyck (ed.), Cicero: De Natura Deorum Book I, Cambridge, 2003, p. 9, 129 (ad 50a), esp. p. 143 (ad 62), etc.

${ }^{9}$ Her., 18, 3-6 (p. 18 de Lannoy). That Philostratus' account pertains to contemporary Rhesuscult is argued by G. SEURE, "Le roi Rhésos et le héros chasseur. Études sur quelques types curieux du cavalier thrace : troisième série," RPh 54 (1928), p. 106-139, here p. 118 n. 1.
} 
him; indeed, Philostratus explicitly mentions a $\beta \omega \mu$ ó $\varsigma$-i.e. sacrificial cult- for Rhesus on the Rhodope mountains. ${ }^{10}$ As a local deity, he was also thought to

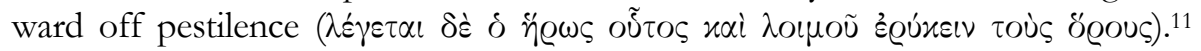
Admittedly, with Philostratus it is never easy to disentangle factual information from fictional elaboration, ${ }^{12}$ and it was recently argued that the author of the Heroicus subsumes factual accuracy to literary or philosophical concerns more often than not. ${ }^{13}$ But even his detractors do not doubt the essential premise of Philostratus' account, namely that a cult of Rhesus did obtain in Thrace; ${ }^{14}$ and specialist scholarship on the Heroicus has recently rehabilitated Philostratus as a connoisseur of local and regional lore, traditions, and ritual practices, which he sought to reassert as against the Panhellenic uniformity imposed by, mainly, Homeric epic. ${ }^{15}$ At any rate, as we shall see in the following section, Philostratus' account of Rhesus' cult at Rhodope has a lot in common with what we know about the cult of the indigenous Heros Equitans; and even if Philostratus is merely confusing the Heros with Rhesus, this could be due at least partly to genuine cultic affinities between the two figures.

We saw earlier that, according to his mother the Muse, Rhesus will posthumously become a 'prophet of Bacchus' (Rh., 972), and will presumably have a privileged role in Bacchic mysteries celebrated locally in the Mt. Pangaeum area by 'those who have knowledge' (973), i.e. the initiates. ${ }^{16}$ Assuming a special role for Rhesus in the mystic cult would be consistent with the play's insistence both on Rhesus' being a cousin of Orpheus (Rh., 944, 966), famously an expounder

${ }^{10}$ Her. XVII, 5 (p. 18 ed. DE LanNoy); cf. SeUre, l.c. (n. 9), p. 120 n. 2; P. Grossardt (ed.), Einführung, Übersetzung und Kommentar zum 'Heroikos' von Flavius Philostrat II, Basel, 2006, p. 439-440.

11 Philostr. Her., 18, 3-6 (p. 18). See also SEURE's, l.c. (n. 9), p. 117-119 minute analysis of the passage, with discussion of textual difficulties on his p. 118 n. 5 . In an earlier publication, SEURE ("Étude sur quelques types curieux du cavalier thrace", RÉA 14 [1912], p. 137-166, 239-261, 382390, here 382-390) had considered the Thracian cult of Rhesus as a 'fétiche prophylactique'. For further (indirect) evidence on the cult of Rhesus in Macedon and Thrace see LIAPIS, l.c. (n. 2), p. 395-396, 408.

12 See e.g. G. Anderson, Philostratus: Biography and Belles Lettres in the Third Century A.D., London, 1986, p. 241-57, esp. 253-4; see also E.L. BOWIE, "Philostratus: Writer of Fiction", in J.R. MORGAN \& R. StOneman (eds.), Greek Fiction: The Greek Novel in Context, London, 1994, p. 181-99.

13 Grossardt, o.c. (n. 10) I, p. 35-7, 115; vol. II, p. 438-41. Principally, Grossardt is suspicious of Philostratus' account because of the impossibility of checking its validity against independent evidence.

14 See e.g. GrossardT, o.c. (n. 10) II, p. 438 (comm. on Her., 17, 3).

15 See J.K. Berenson, E.B. Aitken (eds.), Flavius Philostratus: Heroikos, Atlanta, 2001, p. lxlxxvi, esp. p. lxxi, lxxiv-lxxv.

16 As was seen already by A. MATTHIAE (ed.), Euripidis tragoediae et fragmenta VIII, Leipzig, 1824, ad 969, the reference here is to the Dionysiac mysteries, since 'the mystery cults offered their adepts a supposedly potent kind of knowledge, from which the profane were excluded'

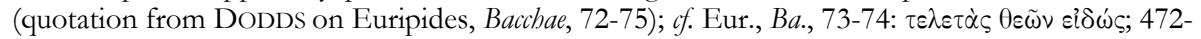

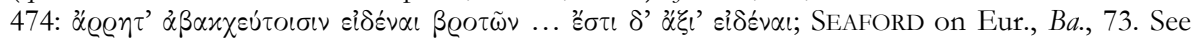
further LIAPIS, l.c. (n. 2), p. 397 n. 83. 
of mystic lore and rites, ${ }^{17}$ and on his being a posthumous denizen of the caves of Mt. Pangaeum (Rh., 970), which is also where Orpheus' dwelling was located according to certain versions of the myth. ${ }^{18}$ Moreover, according to an attractive hypothesis, Rhesus may have been considered the mythical ancestor of the Thracian Bessoi, who acted as prophets in the oracular shrine of Dionysus located in all likelihood on Mt. Pangaeum. ${ }^{19}$

\section{Rhesus and the Heros Equitans}

What little is known about Rhesus' cult in Thrace has sometimes led scholars, beginning with G. Seure, to identify Rhesus, however tentatively, with a divinity whose cult was extremely widespread in the whole Thracian region, namely the so-called Heros Equitans, or 'Thracian Horseman', thus named by modern scholars for lack of evidence for a more specific appellation. ${ }^{20}$ Scholarly opinion on the identification of Rhesus with the Thracian Horseman is anything but unanimous: on the contrary, it ranges from unconditional acceptance ${ }^{21}$ through cautious speculation $^{22}$ to descriptive non-committalism;23 there are, of course, many who simply reject the equation on the grounds of insufficient evidence.

${ }_{17}$ As early as the late 5th century, the Aristophanic 'Aeschylus' could name Orpheus as the originator of, generally, 'rites' (Aristophanes, Ranae, $1032 \tau \varepsilon \lambda \varepsilon \tau \dot{\alpha} \varsigma$ ), which could be mystery rites, although certainty is impossible (see DOVER ad l.; F. GRAF, Eleusis und die orphische Dichtung Athens in vorhellenistischer Zeit, Berlin/New York, 1974, p. 31-33). In the 4th century, Orpheus is more explicitly associated with the founding of the 'holiest of rites' ([Demosth.], 25.11), probably the Eleusinian Mysteries (GRAF, o.c., p. 33); cf. also Plutarch, fr. 212 (ed. SANDBACH). Further on Orpheus' broad associations with mystic rites in general see I.M. LINFORTH, The Arts of Orpheus, Berkeley, 1941, p. 27, 38-104, 169-71, 189-232, 264; cf. LiAPIS, l.c. (n. 2), p. 398-401.

18 Cf. Iamblichus, Vita Pythagorae XVIII, 146 (p. 107, 3 ed. NAUCK); Maximus Tyrius, XXXVII, 6 (p. 300 ed. Trapp $=440$ ed. KOnIARIS); Himerius, Oratio XLVI, 3 (p. 185-186 ed. COLONNA).

19 Thus A.D. NOCK, "The End of the Rhesus," CR 40 (1926), p. 183-186, here 186. V. LiAPIS, "Epicharmus, Asclepiades of Tragilus, and the Rhesus. Lessons from a Lexicographical Entry," ZPE 143 (2003), p. 19-22 suggests that Rhesus' prophetic function may also be alluded to in Epicharmus, fr. 206 (ed. KASSEL-AUSTIN) and in Asclepiades of Tragilos, FGrHist 12 F 5 (ed. JACOBY); $c f$. also LiAPIS, l.c. (n. 2), p. 397. For epigraphic evidence on the Bessoi see P.A. Dimitrov, Thracian Language and Greek and Thracian Epigraphy, Newcastle, 2009, p. 48.

20 See imprimis Seure, l.c. (n. 9), esp. p. 113-139. On the Heros Equitans in Thrace see also G. Kazarow, RE Suppl. III (1918), p. 1132-1148; V. Velkov \& V. Gerassimova-Tomova, ANRW II 18.2 (1989), p. 1322-1330. For bibliography see A. Cermanovic-Kuzmanovic et al., LIMC VI.1 (1992), p. 1019-1081 (here 1021). Selection of basic literature also in R. TuRCAN, The Cults of the Roman Empire, transl. A. Nevill, Oxford, 1996, p. 371 n. 1.

${ }^{21}$ E.g. F. BENoîT, L’héroïsation équestre, Paris, 1954, p. 60: 'Rhésos [...] n'est que la personification du "héros chasseur", auquel la légende attribuait une individualité'.

${ }^{22}$ E.g. Perdrizet, o.c. (n. 6), p. 20: 'peut-être Rhésos est-il, je ne veux pas dire le vrai nom, mais l'un des surnoms du personnage divin figuré sur ces stèles' [i.e. the Heros Equitans].

23 E.g. W. BAege, De Macedonum sacris, diss., Halle, 1913, p. 201 who limited himself to identifying the Heros as a deum a Thracibus cultum. 
It must be admitted that the identification of the Heros with Rhesus is wholly uncertain. It is hardly made more credible by the fact that the Heros, although often identified on figured monuments with various divinities (e.g. Apollo, Asclepius, Dionysus, the Dioscuri), ${ }^{24}$ is never explicitly associated with Rhesus. On the other hand, positive evidence for such an association would be extremely hard to come by if, as has been suggested, " $\tilde{\eta} \sigma o \varsigma$ is not a divine name but (perhaps in accordance with Thracian custom) ${ }^{25}$ a vague designation meaning 'lord', 'sovereign' or the like. Indeed, a widely accepted etymology associates the name of Rhesus with the Indo-European root $*(H) r e \hat{g}-$, which has produced Latin rex, Vedic râj-, Gallic -rix, and Gothic reiks. ${ }^{26}$ It is interesting that the Heros Equitans is

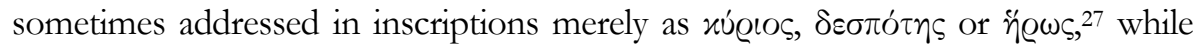
on several occasions the dedication $\ddot{\eta} \varrho \omega$ is accompanied by a (presumably indigenous) designation, such as $\mathrm{A}^{\sim} \mathrm{ZHN} \Omega, \Delta \Omega \Sigma \mathrm{AHN} \Omega, \mathrm{EI} \Sigma \mathrm{A} \Sigma \mathrm{HMH}$,

${ }^{24}$ Dionysus: KazArow, o.c. (n. 20), p. 1144; CermanoviC-KuZMANOviC et al., o.c. (n. 20), no. 374; Dioscuri: KazArow, o.c. (n. 20), p. 1143-1144; Cermanovic-KuZMANOviC et al., o.c. (n. 20), no. 456. For Apollo and Asclepius see below n. 33.

25 Cf. PERDrizet, o.c. (n. 6), p. 17-21, esp. p. 20-21.

26 For this etymology - which goes back to W. TOMASCHEK, "Die alten Thraker: Eine ethnologische Untersuchung. II. Die Sprachreste. 1. Hälfte: Glossen aller Art und Götternamen," Sitzungsberichte der philosophisch-historische Classe der kaiserlichen Akademie der Wissenschaften 130, II. Abhandlung, 1-70, Vienna 1893, p. 53f. - see esp. P. KRETSCHMER, Einleitung in die Geschichte der griechischen Sprache, Göttingen, 1896, p. 126; SEURE, l.c. (n. 9), p. 106-112; PERDRIZET, o.c. (n. 6), p. 17-18 with n. 7, p. 20-21; KAZAROW, o.c. (n. 20), p. 1147; É. BOISACQ, "L'étymologie du grec

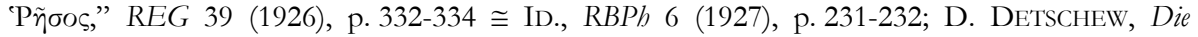
thrakischen Sprachreste, Vienna, 1957, p. 393 s.v. ' $\eta \sigma x o u-'$, who further points out that "“ $\tilde{\eta} \sigma(\sigma)$ os and Rhesus are also attested epigraphically as personal names; P. WATHELET, "Rhésos ou la quête de l'immortalité," Kernos 2 (1989), p. 213-231, here p. 222 with n. 38; Y. UsTiNOVA, “Either a Daimon, or a Hero, or Perhaps a God': Mythical Residents of Subterranean Chambers," Kernos 15 (2002), p. 267-288, here p. 283 n. 153; for discussion cf. also REMPE, o.c. (n. 7), p. 26; K. MCCONE, "'King' and 'Queen' in Celtic and Indo-European," Ériu 49 (1998), p. 1-12; M.L. WEST, IndoEuropean Poetry and Myth, Oxford, 2007, p. 412-413. Later, however, P. KRETSCHMER, "Das -ntSuffix," Glotta 14 (1925), p. 84-106 (here p. 103), changed his mind, and suggested that " $\tilde{\eta} \sigma o \varsigma$ derives from a root *rèsku- meaning 'brisk, spirited, vigorous'; cf. such proper names as

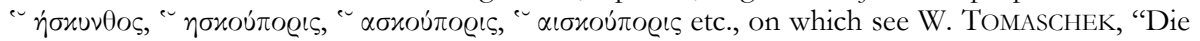
alten Thraker: Eine ethnologische Untersuchung. II. Die Sprachreste. 2. Hälfte: Personen und Ortsnamen," Sitzungsberichte der philosophisch-historische Classe der kaiserlichen Akademie der Wissenschaften 131, I. Abhandlung, 1-103, Vienna, 1894, p. 27-28; also DimiTrov, o.c. (n. 19), p. 104. This no doubt holds good for the river name ( ${ }^{e} \tilde{\eta} \sigma o s$ in the Troad), but hardly for the hero: see DETSCHEW, o.c., p. 393. For a more recent challenge to the canonical etymology see R. SCHMITT, "Bemerkungen zu den Namen des Thrakerkönigs Rhesos und seines Vaters," in M. FRITZ \& S. ZEILFELDER (eds.), Novalis indogermanica: Festschrift für Günter Neumann zum 80. Geburtstag, Graz, 2002, p. 443-452, here p. 443-448, with the rather flimsy argument that " $\tilde{\eta} \sigma o \varsigma$ has yielded

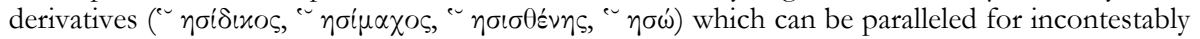

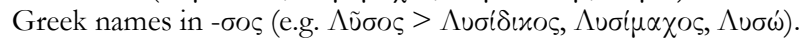

27 Cf. e.g. SEure, l.c. (n. 9), p. 122-127; CERMANOviC-KuZMANOvic et al., o.c. (n. 20), p. 1020,

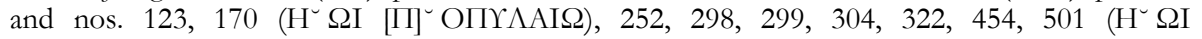

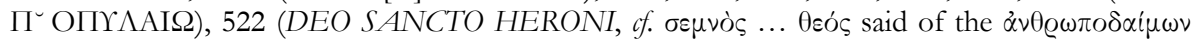

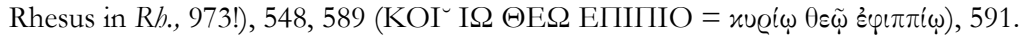




\section{ZEIN $\Delta^{\smile}$ OYMHN $\Omega, \mathrm{KA}^{\smile} \mathrm{ABA} \Sigma \mathrm{M} \Omega, \Pi \mathrm{H}^{\smile} \mathrm{MH}^{\smile} \mathrm{O} \Lambda \mathrm{A}, \quad \Sigma \mathrm{A} \Lambda \Delta \mathrm{OKE} \Lambda \mathrm{HN} \Omega$ etc. ${ }^{28}$}

This plurality of names calls for a brief digression. Are we dealing with different appellations of a single god or hero? And if yes, do these appellations correspond to different avatars of the god/hero, or are they simply evidence of a

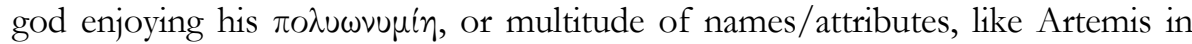
Callimachus' Third Hymn? The latter seems more likely, in view of the fact that a high degree of individualization, such as would perhaps befit individual avatars, is precluded by the observation that the Hero's appellations, for the most part, do not evince any individual characteristics. They are by and large generic names singling out or invoking some of the functions a hero is expected to perform

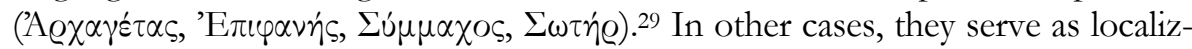
ers, pinpointing the hero's epichoric influence (Aủ $\lambda \omega v \varepsilon i \tau \eta s, ~ ' E \lambda \lambda \eta \sigma \pi o ́ v \tau \iota$ s,

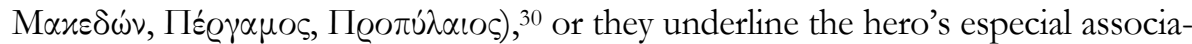
tion with horses ('I $\pi \pi \alpha \lambda x \mu \rho \varsigma$, 'I $\left.\pi \pi \delta^{\prime} \tau \eta \varsigma\right) .{ }^{31}$ Finally in a number of instances, the Hero's appellations evince a special connection with healing gods, notably Apollo and Asclepius, ${ }^{32}$ which is hardly surprising given the healing powers attributed both to the Hero (see next paragraph) and to Rhesus (see p. 97 above). In a few cases, it appears that dead (presumably heroized) individuals are depicted in the guise of the Heros, but such cases are not numerous (no more than five or six, cf. n. 30 above). The crux of the matter lies, of course, in such undecipherable appellations of the Hero as those mentioned at the end of the previous paragraph. Given the current state of the evidence, it is simply impossible to ascertain whether they refer to aspects of the same deity or to different deities.

Nomenclature aside, Rhesus and the Heros Equitans share striking similarities. To begin with, both of them are healing deities. For Rhesus we have Philostratus' evidence that he was thought to ward off pestilence (see p. 97 above); the Heros assumes, in a number of artistic representations, the features of Apollo or of

28 For a list of these appellations see CERMANOviC-KuZMANOvic et al., o.c. (n. 20), p. 1020, and nos. 120, 126, 179, 210, 305, 309, 310-12, 446, 494, 506, 529, 576, 584. For the epigraphic evidence see DimiTrov, o.c. (n. 19), p. 39, 40, 42, 44, 48, 49, 53, 54, 70, 74, 76, 77, 79, 80, 82, 83, 92, 93, 98, 100, 101, 102, 103, 106, 109, 111-15, 118.

29 See Cermanovic-Kuzmanovic et al., o.c. (n. 20), p. 1020.

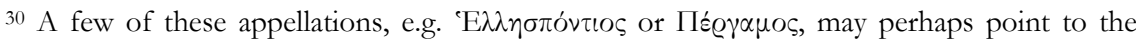

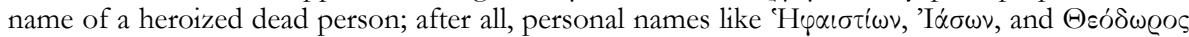
are found on depictions of the Horseman; of. CERmanovic-KuzMANOvic et al., o.c. (n. 20), p. 1020, and nos. 8, 33, 40, 76, 170, 230, 501, 537.

31 Cf. Cermanovic-Kuzmanovic et al., o.c. (n. 20), p. 1020, and no. 518.

32 In these instances, the Hero is often identified simply as "Apollo", "god Apollo", "Asclepius", "Lord Asclepius" and the like; in many cases, however, the dedication $А П О \Lambda \Lambda \Omega N I$ or $\mathrm{A} \Sigma \mathrm{K} \Lambda \mathrm{H} \Pi \mathrm{I} \Omega$ is accompanied by undecipherable (presumably indigenous) names, e.g. АПО $\Lambda$ -

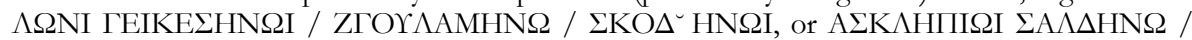

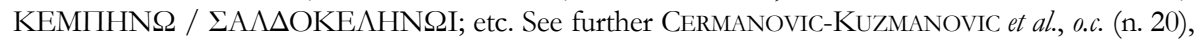
p. 1020, and nos. 464 (cf. 593), 511, 480; 211, 315, 508. 
Asclepius. ${ }^{33}$ Albeit representing a fairly rare motif, Rhesus' transformation from killer to healer is by no means anomalous. One need only think of Amphiaraus, a warrior as well as a seer, whose shrine at Oropus was a popular healing oracle; ${ }^{34}$ and of Achilles (with whom Rhesus has several striking resemblances), ${ }^{35}$ who had been taught the art of healing by Chiron (Iliad XI, 831-832). The motif has several parallels in Old Irish epic, especially in the case of Finn mac Cumaill, a warrior who was trained as a seer (cf. Rhesus' posthumous status as 'prophet of Bacchus', $R h ., 972$ ) and was in possession of a healing drink. ${ }^{36}$

Moreover, Rhesus is famously the master of marvellous steeds, ${ }^{37}$ and Philostratus, as we saw (p. 96 above), tells us that in actual Thracian cult he was worshipped, among other things, as a horse-breeder; the Heros Equitans is also typically depicted as a rider (hence his modern, faute de mieux name). Further, on a great many reliefs the 'Thracian Horseman' is shown as a hunter, ${ }^{38}$ which is another point of contact with Rhesus, an accomplished hunter in Philostratus' and Parthenius' accounts. ${ }^{39}$ Remarkably, images of the 'Thracian Horseman' as a hunter are often accompanied by representations of wild animals (boars, hares, deers etc.) near altars, no doubt as a sign that they are about to be sacrificed; ${ }^{40}$

33 Identification with Apollo: KAZAROw, o.c. (n. 20), p. 1143; CERMANOVIC-KuZMANOVIC et al., o.c. (n. 20), p. 1020, and nos. 178, 220, 302, 465, 466, 480, 497, 499, 511, 587, 592, 593, 620, 622; Heros holding a lyre, like Apollo: CermanoviC-KuzMANOvic et al., o.c. (n. 20), nos. 262-265; cf. G. SEurE, "Musée de Belgrade. Reliefs votifs inédits et disparus," REA 26 (1924), p. 30-67, here p. 61. Identification with Asclepius: KAZAROW, o.c. (n. 20), p. 1143; CERMANOviCKuZMANOvic et al., o.c. (n. 20), p. 1020, and nos. 124, 162, 180, 182, 211, 266, 301, 315, 369, 370, 448, 498, 504, 508-10, 523, 543, 575-6; for early findings of Heros/Asclepius see SEURE, l.c. (n. 9), p. 135-136; cf. also PERDRIZET, o.c. (n. 6), p. 19-21. For a comprehensive treatment, with a study of the evidence bearing on Asclepius' syncretism with the Heros Equitans in iconography, see I. Dontcheva, "Le syncrétisme d'Asclépios avec le Cavalier Thrace," Kernos 15 (2002), p. 317 324. On the Heros' healing properties see also TurCAN, o.c. (n. 20), p. 249.

34 See P. Bonnechere, Trophonios de Lébadée. Cultes et mythes d'une cité béotienne au miroir de la mentalité antique, Leiden, 2003, p. 96-97 with n. 4; Y. UstinovA, Caves and the Ancient Greek Mind, Oxford, 2009, p. 97.

35 On these resemblances see V. LIAPIS, "Rhesus: Myth and Iconography," in J.R.C. CousLAND, J.R. Hume (eds.), The Play of Texts and Fragments: Essays in Honour of Martin Cropp, Leiden, 2009, p. 273-91, here p. 282-283.

36 See D.A. Miller, The Epic Hero, Baltimore/London, 2000, p. 325-326.

37 Iliad X, 435-437; Hipponax, fr. 72, 5-6 (ed. WEST); Rh., 303-304.

38 Ample documentation in CERMANOVIC-KuZMANOVIC et al., o.c. (n. 20), nos. 444-574, 583603, and p. 1070-1072. For detailed discussion of ten Belgrade reliefs depicting the Thracian Horseman as a hunter see SEURE, l.c. (n. 33), p. 48-67.

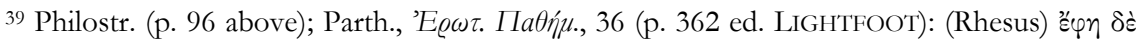

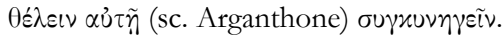

40 Cf. e.g. N. Hampartumian, Corpus Cultus Equitis Thracii IV, Leiden, 1979, nos. 16, 18, 19, 21, 37, 59, 74, 93, 120, 138; A. Cermanovic-Kuzmanovic, Corpus Cultus Equitis Thracii V, Leiden, 1982, nos. 1, 10, 13, 34, 35, 44, 47, 48, 51, 65, 76, 85, 88; Z. GoČEva \& M. OppermanN, Corpus Cultus Equitis Thracii I, Leiden, 1979, nos. 2, 13, 54, 61, 85-7, 92, 95, 123, 128, 151; ïdem, Corpus Cultus Equitis Thracii II.1, Leiden, 1981, nos. 175, 224, 244, 260, 273, 281, 313, 328, 361-2, 367, 379, 415-16, 427, 430; iidem, Corpus Cultus Equitis Thracii II.2, Leiden, 1984, nos. 447, 457 (six beasts 
and we recall that, according to Philostratus (p. 97 with n. 10 above), Rhesus' altar on Mt. Rhodope was frequented by wild animals that offered themselves willingly to be sacrificed to him. Of special interest in this respect is a relief from Glava Panega (near Lukovit, Bulgaria). ${ }^{41}$ The upper register depicts the Hero in a hunter's guise chasing a boar towards the relief's right side, where an altar is shown. The lower register shows four animals (a boar, a doe, a deer, and a bull) running towards the relief's right side. As they do so without being pursued, it has been suggested that they may be offering themselves for sacrifice, especially since the bull is kneeling just underneath the altar depicted above him in the upper register's far right. ${ }^{42}$ Others, however, see here merely a variant of the regular, run-of-the-mill animal fight. ${ }^{43}$

There are further similarities. As a cave-dweller, Rhesus is a chthonic figure. By virtue of his disappearing 'inside the caverns of the silver-veined land' in Mt Pangaeum (Rh., 970) while at the same time escaping death, Rhesus the 'man-god' (Rh., 971) appears to be in a position authoritatively to manoeuvre his contacts with the Beyond - hence, presumably, his central role in the Bacchic mysteries of Mt Pangaeum (see above p. 97-98). Likewise, the Heros Equitans is extensively associated with the Underworld: stelae bearing his depictions have been found in graves and grave-mounds; 44 he is sometimes associated with Totenmabl iconography, ${ }^{45}$ or depicted in the company of heroized dead; 46 and he is extremely often shown in connection with serpents, whose chthonic associations are well

around the altar!), 458, 464, 469, 470, 484, 524, 560. Cf. also CERMANOVIC-KuZMANOviC et al., o.c. (n. 20), p. 1031, nos. 109-112; 1032, no. 126, 126bis; 1033 nos. 146-147; 1034-1036, nos. 161-165, 171-185, 202-203, 206-213; 1037, nos. 235-238, 247-9; 1054-1056, nos. 485-514.

41 See Cermanovic-Kuzmanovic et al., o.c. (n. 20), no. 543. The relief is fully described and discussed in SEURE, l.c. (n. 9), p. 134-136, no. 4.

42 The interpretation is that of SEURE, l.c. (n. 9), p. 135 with n. 3, 4. For further examples see D.C. SAMSARIS, in Dritter Internationaler Thrakologischer Kongress zu Ehren W. Tomascheks II, Sofia, 1984, p. 284-289, here 288 n. 5.

43 Thus G.I. Kazarow, Die Denkmäler des Thrakischen Reitergottes in Bulgarien. I Textband, II Tafelband, Budapest/Leipzig, 1938, I p. 72-3; M. OpPermann, LIMC VI.1 (1992), p. 1058. A relief from Ostia (on which see M. FLORIANI SQUARCIAPINO, I culti orientali ad Ostia, Leiden, 1962, p. 67) shows the Heros as a hunter, while a boar runs towards an altar with a hound hard on its heels. Despite TuRCAN, o.c. (n. 20), p. 250, however, this does not imply that the boar is willingly offering itself to be sacrificed; for it is very obviously being chased. It is at any rate noteworthy that Ostia, where this Heros relief comes from, has yielded several funerary inscriptions documenting the presence of Bessoi (CIL XIV, 234, 236, 240; FLORIANi SQuARCIAPINO, o.c., p. 68 with n. 1; TURCAN, o.c. [n. 20], p. 250), i.e. precisely of those Thracians who probably claimed Rhesus as their ancestor (see n. 19 above).

44 See e.g. KaZAROW, o.c. (n. 20), p. 1133, 1140.

45 See Hampartumian, o.c. (n. 40), index, s.v. 'funeral feast'; Gočeva \& Oppermann, Corpus Cultus Equitis Thracii I (as in n. 40), nos. 54, 55, 170, 171; CERMANOviC-KuzMANOviC, o.c. (n. 40), nos. 64, 89 .

46 See Cermanovic-Kuzmanovic et al., o.c. (n. 20), nos. 56-60, 388-395, 565-570, 603, 638-639. 
known. ${ }^{47}$ Finally, depictions of the Heros Equitans in Thrace and its environs often show him in association with Dionysus, Sileni, grapevines, and other Bacchic accoutrements, ${ }^{48}$ which cannot fail to recall Rhesus' posthumous status as 'prophet of Bacchus' (Rh., 972). Sometimes, the Bacchic and the chthonic are interconnected in the iconography - as indeed they are in the person of Rhesus himself, the cave-dweller who is posthumously assigned a special function in Dionysus' mysteries. ${ }^{49}$ Thus, on one occasion, the Heros is sculpted on a funerary stela of Bacchic initiates from Mt. Pangaeum, the very seat of Rhesus the 'prophet of Bacchus'.50 Another funerary relief from neighbouring Thassos, erected in memory of Auphonios and Auphonia (presumably a married couple),

47 See Hampartumian, o.c. (n. 40), nos. 118, 143, and index s.v. 'tree, snake-entwined'; Goceva \& Oppermann, Corpus Cultus Equitis Thracii I (as in n. 40), index, s.v. 'Schlange'; iidem, Corpus Cultus Equitis Thracii II.1 (as in n. 40), index, s.v. 'Schlange'; Cermanovic-KuZManovic, o.c. (n. 40), index s.v. 'Schlange'; GoČeva \& Oppermann, Corpus Cultus Equitis Thracii II.2 (as in n. 40), index, s.v. 'Schlange'; Cermanovic-KuZMANOvic et al., o.c. (n. 20), nos. 104-108, 113-126, 145, 148-154, 166-185, 204-213, 231-214, 240-249. Despite BENOÎT, o.c. (n. 20), p. 57, who is followed by TURCAN, o.c. (n. 20), p. 249 with n. 5, the serpent depicted under the Hero's horse on the stele from Karaisen in Veliko Tărnovo (GočEva \& Oppermann, Corpus Cultus Equitis Thracii II.2 [as in n. 40] no. 674) has nothing menacing; on the contrary, it is peacefully coiled around itself, as in so many other representations; after all, as far as I can see the Heros is never represented as a dragon-slayer. For the association between snakes and the chthonic realm see M.P. NiLsson, Geschichte der griechischen Religion I, Munich, 196733, p. 198-199; E. KüsTER, Die Schlange in der grieschischen Kunst und Religion, Gießen, 1913, p. 62-119; S.M. BocK, "Die Schlange im Traum der Klytaimestra," Hermes 71 (1936), p. 230-236, here p. 231 with n. 1-2; J. DigGLE (ed.), Theophrastus Characters, Cambridge, 2004, p. 357; for comparative perspectives see O. WASER, "Über die äußere Erscheinung der Seele in den Vorstellungen der Völker, zumal der alten Griechen," $A R W 16$ (1913), p. 336-388, here p. 354-356; W. WundT, Elements of Folk Psychology, transl. E.L. Schaub, London, 1916, p. 190-191, 214, 368. Ovid (Met. XV, 389-390) and Aelian (Hist. an. I, 51) report the notion that the backbones of the wicked dead turn into snakes; a

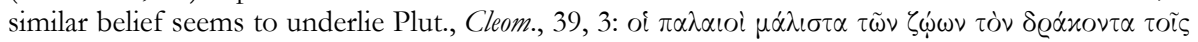

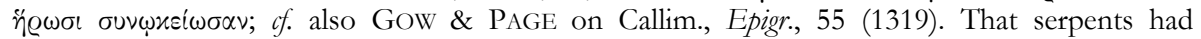
chthonic associations in Thrace too cannot, of course, be proved, although it is argued, fairly tendentiously, by KAZAROw, o.c. (n. 20), p. 1145.

48 See Seure, l.c. (n. 11), p. 240-242; Benoît, o.c. (n. 20), p. 59-60; Hampartumian, o.c. (n. 40), nos. 33, 34, 56, 92, ?93, 115; GoČEva \& Oppermann, Corpus Cultus Equitis Thracii II.1 (as in n. 40) no. 192; Cermanovic-Kuzmanovic et al., l.c. (n. 20) no. 372-375, 561, 577; cf. also TurCAN, o.c. (n. 20), p. 250 with n. 11-13. As early as the early 20th century, PERDRIZET, o.c. (n. 6), p. 21 suggested that the Heros Equitans may, like Rhesus, have affinities with Dionysus, and went as far as

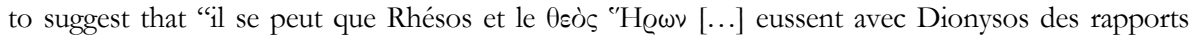
d'affinité, qu'ils fussent même, en quelque sorte, des hypostases du grand dieu thrace."

49 On Dionysus' proximity to the Underworld see, in general, H. Jeanmaire, Dionysos, Paris, 1951, p. 268-78; in Macedonia in particular: BAEGE, o.c. (n. 23), p. 91-93. For Dionysus' chthonic associations in the pictorial record see H. METZGER, "Dionysos chthonien d'après les monuments figurés de la période classique," BCH 68/69 (1944/5), p. 296-339. On Rhesus as a prophetic cave-dweller beyond death, and on other comparable cult figures see RoHDE, o.c. (n. 6), p. 88-114; cf. NOCK, l.c. (n. 19), p. 186; E. Vermeule, Aspects of Death in Early Greek Art and Poetry, Berkeley, 1979, p. 216-217 n. 42; above all, see UstiNOvA, l.c. (n. 26) and eadem, o.c. (n. 34), p. 89109. Cf. also LiAPIS, l.c. (n. 2), p. 398-406.

50 See PerdrizeT, o.c. (n. 6), p. 23, pl. I; idem, "Inscriptions de Philippes," BCH 24 (1900), p. 299-323, here p. 304-305 with pl. XIII. 
shows the Horseman being given a (Dionysiac?) ivy-branch by a feminine figure, who as has been suggested might be a chthonic figure such as Persephone. ${ }^{51}$

This brief survey of the Heros' iconography indicates that, although no predictable or consistent patterns can be established, a relatively small number of basic motifs predominates. As we have seen, the Heros is always depicted as a horseman, with further variations including the Horseman as a hunter, a healer, a cult figure associated with sacrificial ritual or with the chthonic realm, or as a warrior. ${ }^{52}$ This relatively limited range of iconographic motifs and attributes is consistent with the hypothesis that the Heros Equitans represents a single figure of cult rather than a plurality of divinities who simply happen to be depicted, more or less often, as riders. This hypothesis is considerably corroborated by the observation, substantiated in the preceding discussion, that the basic iconographic attributes of the Heros are typically associated, in myth or cult, with Rhesus.

In conclusion, the association between Rhesus and the Heros Equitans, although unprovable on the evidence currently available, is nonetheless strongly suggested by the parallelisms delineated above. The thesis for their association may be further bolstered, however indirectly, by arguments put forth in an earlier paper of mine, ${ }^{53}$ to the effect that what little may be gleaned about the cult of Rhesus in Thrace seems incompatible with the cult of Rhesus as practiced in the Athenian colony of Amphipolis. The latter conformed to well-known patterns of Greek hero-cult: the tomb where Rhesus' talismanic remains were thought to lie was the centre of cultic activity. By contrast, the Thracian cult of Rhesus, as evidenced in Rhesus and in Philostratus, seems to have shared none of the essential qualities of this standard type of Greek hero-cult, since he had no visible tomb, merely an unspecified posthumous dwelling somewhere in Mt Pangaeum (Rh., 970-973); indeed, he was not even thought of as being dead, since his mother had arranged for his soul to be released from Hades (Rh., 962-966).

Vayos LIAPIS

Graduate Programme in Theatre Studies

Open University of Cyprus

P.O. Box 24801

CY - 1304 NicosiA

E-mail:vayos.liapis@ouc.ac.cy

51 Thus BENOÎT, l.c. (n. 20), p. 60 with pl. IX.2, who has rightly seen that the Heros' raised right hand does not hold a spear (pace CERMANOvic-KuzManovic et al., l.c. [n. 20], no. 339: 'die R. mit der Lanze erhoben'); rather, it makes the gesture of benedictio latina ( $c f$. also the photo in LIMC VI.2 [1992] 695). BENOÎT, l.c. (n. 20), p. 61-64 also advances the hypothesis that, on funerary reliefs, the Heros could represent the heroised dead; cf. p. 100, with n. 30 above.

52 For depictions of the Heros as a soldier/warrior see e.g. CermanOvic-KuzMANOviC et al., l.c. (n. 20), p. 1062-1064, nos. 604-639.

${ }^{53}$ LIAPIS, l.c. (n. 2), p. 408-411. 